\title{
The migration of pesticide residues in groundwater at a bank filtration site (Krajkowo well field, Poland)
}

\author{
Krzysztof Dragon $^{1}$ (1) $\cdot$ Dariusz Drozdzynski $^{2} \cdot$ Jozef Gorski $^{1} \cdot$ Roksana Kruc $^{1}$
}

Received: 21 December 2018 / Accepted: 23 September 2019 / Published online: 4 October 2019

(c) The Author(s) 2019

\begin{abstract}
River bank filtration systems are widely used for water supply purposes. Using these systems, the movement of water over short distances between the river bottom and extraction wells can decrease the concentrations of some contaminants. Such systems are especially important for the removal of specific micro-pollutants that seasonally appear in river water. In this article, pesticides migration at the Krajkowo well field is analysed based on different water extraction schemes. The water is extracted by two groups of wells (one located 60-80 m from the Warta River, and the second located more than $400 \mathrm{~m}$ from the river) and by a horizontal well with radial drains located $5 \mathrm{~m}$ below the river bottom. Based on this scheme, the rate of pesticide residues removal was analysed in wells located at different distances from the river channel. The results of the three sampling campaigns conducted in summer and autumn 2017 and winter 2018 indicate the presence of pesticide compounds in the Warta River (max. total concentration of $0.171 \mu \mathrm{g} / \mathrm{l}$ ). The pesticides were also present in the horizontal well (max. total concentration of $0.137 \mu \mathrm{g} / \mathrm{l})$. Much smaller concentrations (max. $0.064 \mu \mathrm{g} / \mathrm{l}$ ) were observed in vertical wells located 60-80 $\mathrm{m}$ from the river. Additionally, in the well located $250 \mathrm{~m}$ from the river, only two pesticide constituents were detected (at concentrations just above the detection limit), and in a well located $680 \mathrm{~m}$ from the river, the concentrations of pesticide residues were below the detection limit (excluding isoproturon, which was slightly above the detection limit). This research illustrates the effectiveness of pesticides removal by river bank filtration.
\end{abstract}

Keywords River bank filtration $\cdot$ Pesticides in groundwater $\cdot$ Contaminant retardation/removal

\section{Introduction}

River bank filtration (RBF) is a widely used system for water supply purposes. During relatively short periods of water movement between the river bottom and abstraction wells, water quality improvements occur via a series of chemical, biological and physical processes, including biodegradation,

This article is a part of the Topical Collection in Environmental Earth Sciences on "Groundwater Resources and Sustainability" guest edited by Nam C. Woo, Xiaosi Su, Kangjoo Kim and YuChul Park.

Krzysztof Dragon

smok@amu.edu.pl

1 Department of Hydrogeology and Water Protection, Institute of Geology, Adam Mickiewicz University in Poznań,

Bogumiła Krygowskiego 12, 61-680 Poznań, Poland

2 Department of Pesticide Residue Research, Institute of Plant Protection-National Research Institute, Władysława Węgorka 20, 60-318 Poznań, Poland adsorption, chemical precipitation, etc. (Hiscock and Grischek 2002).

RBF sites are typically located in river valleys that are regional discharge zones for shallow as well as deep groundwater flow systems. Extracted water includes various mixtures of bank-filtrated water and ambient groundwater (Forizs et al. 2005; Lasagna et al. 2016), which dilutes the concentrations of contaminants in river water.

Due to the nature of RBF systems, the quality of extracted water is strongly dependent on the water quality of the source river (Górski et al. 2019). Special focus is placed on dissolved organic carbon (DOC) removal, because of the formation of disinfection by-products during the chlorination of water (Ray et al. 2002; Sandhu et al. 2011; Ghodeif et al. 2016). In recent years, emerging contaminants (including organic micropollutants) have become more problematic, especially at RBF sites (Kovačević et al. 2017; Dragon et al. 2018). The increased use of plant protection products (mainly pesticides) has led to the contamination of rivers in many European countries (Guzzella et al. 2006; 
Loos et al. 2010; Köck-Schulmeyer et al. 2014). Additionally, the contamination of groundwater by synthetic organic chemicals (SOCs) is a growing concern (especially at RBF sites), because it can lead to potentially negative effects on human health (Postigo and Barcelo 2015). In this context, European Union (EC 1998, 2006) and Polish regulations (Rozporządzenie 2017) have established a maximum acceptable concentration of $0.1 \mu \mathrm{g} / \mathrm{l}$ for individual pesticides and their degradation products and of $0.5 \mu \mathrm{g} / \mathrm{l}$ for the total pesticides concentration.

The widespread use of pesticides in agriculture has led to many benefits, including enhanced crop quality and quantity. Thus, the use of pesticides during cultivation has a very important effect on the harvest quality and yield. Regrettably, pesticides and their degradation products can contaminate different environmental components, including surface water and groundwater. These potentially adverse impacts on the environment and public health have caused considerable social and scientific concerns around the world. The contamination of water resources by pesticides and other micro-pollutants is one of the major objectives for the preservation and sustainability of the environment. The quantities of potentially hazardous chemicals that can reach the environment in areas of intensive agricultural activities are very large and new substances are constantly being released. It is notable that in Poland, more than 2000 plant protection products (PPPs) are registered for use and they contain approximately 220 different active substances. The main groups of PPPs are herbicides (nearly 900 PPPs), fungicides (more than 700 PPPs) and insecticides (approximately 300 PPPs). In this context, concentration, fate and behaviour data for pesticide residues in the environment are urgently needed.

RBF systems can attenuate SOC migration at different scales depending on the surface water system, local geological setting, well locations (in relation to the river) and system construction. However, the retardation of organic contaminants may be difficult and some products can accumulate in the soil-aquifer system. Although many of these products have been banned (e.g., herbicide atrazine in the European market since 2004), they are occasionally detected in groundwater (Loos et al. 2010; Reh et al. 2013; KöckSchulmeyer et al. 2014). Pesticide residues were previously detected in Poland during investigations of shallow soil sediments, surface water and shallow groundwater. For example, in wells in the Grójec region (Mazowsze Province), PPPs from different groups of pesticides were detected (Badach et al. 2007). Field channels and drainage systems associated with oilseed rape production were analysed for insecticide levels in Wielkopolska Province (Drożdżyński 2008). Additionally, the degradation products of atrazine were detected in sediments and surface waters of the Silesia region (Barchańska et al. 2017).
The quality of water extracted at RBF sites is sensitive to climate changes (Sprenger et al. 2011). The behaviour of SOCs is influenced by the occurrence of weather extremes (especially long wet seasons) that influence both the circulation of SOCs in the hydrogeological environment (elution of SOCs in the soil zone and transport to groundwater and surface water) and the exploitation conditions of an RBF site.

The objective of the present study is to investigate the behaviour of SOCs during bank filtration in wells located at different distances from the river. An analysis of SOCs migration to different types of wells (vertical and horizontal) is also performed. The research was conducted around three sampling campaigns launched in summer and autumn 2017 and winter 2018. The investigation was carried out to assess the vulnerability of bank filtration schemes to SOCs contamination.

\section{The study area}

The Krajkowo well field was selected as the study area to investigate the behaviour of SOCs in RBF systems (Fig. 1). The Krajkowo well field is located in the central part of the Wielkopolska region (Poland) and supplies water to Poznań city. Favourable hydrogeological conditions occur, because the sediments of two groundwater bodies, the Warszawa-Berlin ice marginal valley aquifer (shallow) and the Wielkopolska buried valley aquifer (deep), overlap. The total thickness of the water-bearing sediments is $40 \mathrm{~m}$. The sediments of the deep aquifer are composed of coarse sands and gravels beneath fine sands in the upper part (Fig. 2). The shallower aquifer is also characterised by coarse sands in the deeper part and fine sands near the surface of the aquifer. These aquifers are locally separated by an aquiclude composed of glacial till (Przybylek and Dragon 2017). The water-bearing sediments are of the Quaternary age, while the bottom of the aquifer is composed by Neogene clays.

The well field comprises two main groups of wells (Fig. 1):

- The first group is located in the flood plain on the south bank of the Warta River, 60-80 m from the river bank (RBF-c). This group includes 29 vertical wells with screens located in the deep aquifer.

- The second group is located (at a higher elevation) between 400 and $1000 \mathrm{~m}$ away from the river. This group includes 56 vertical wells. This part of the well field is not continuously exploited. For the purpose of this study, only the portion of the well group shown in Fig. 1 (RBFf) was continuously pumped for a period of 2 years.

The horizontal well (HW) is located on the south side of the river. This well receives water from eight radial drains 


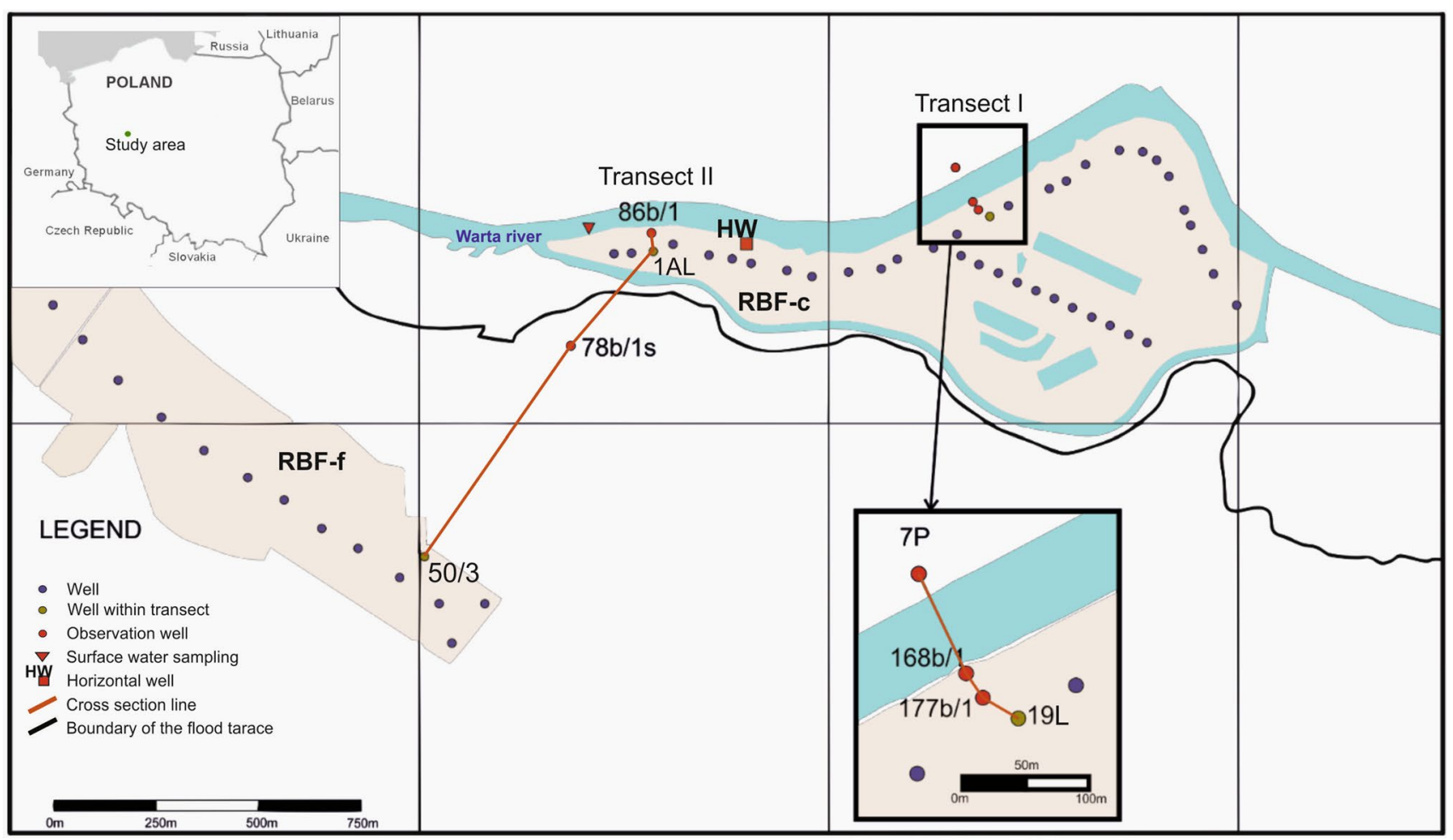

Fig. 1 Map of the study area
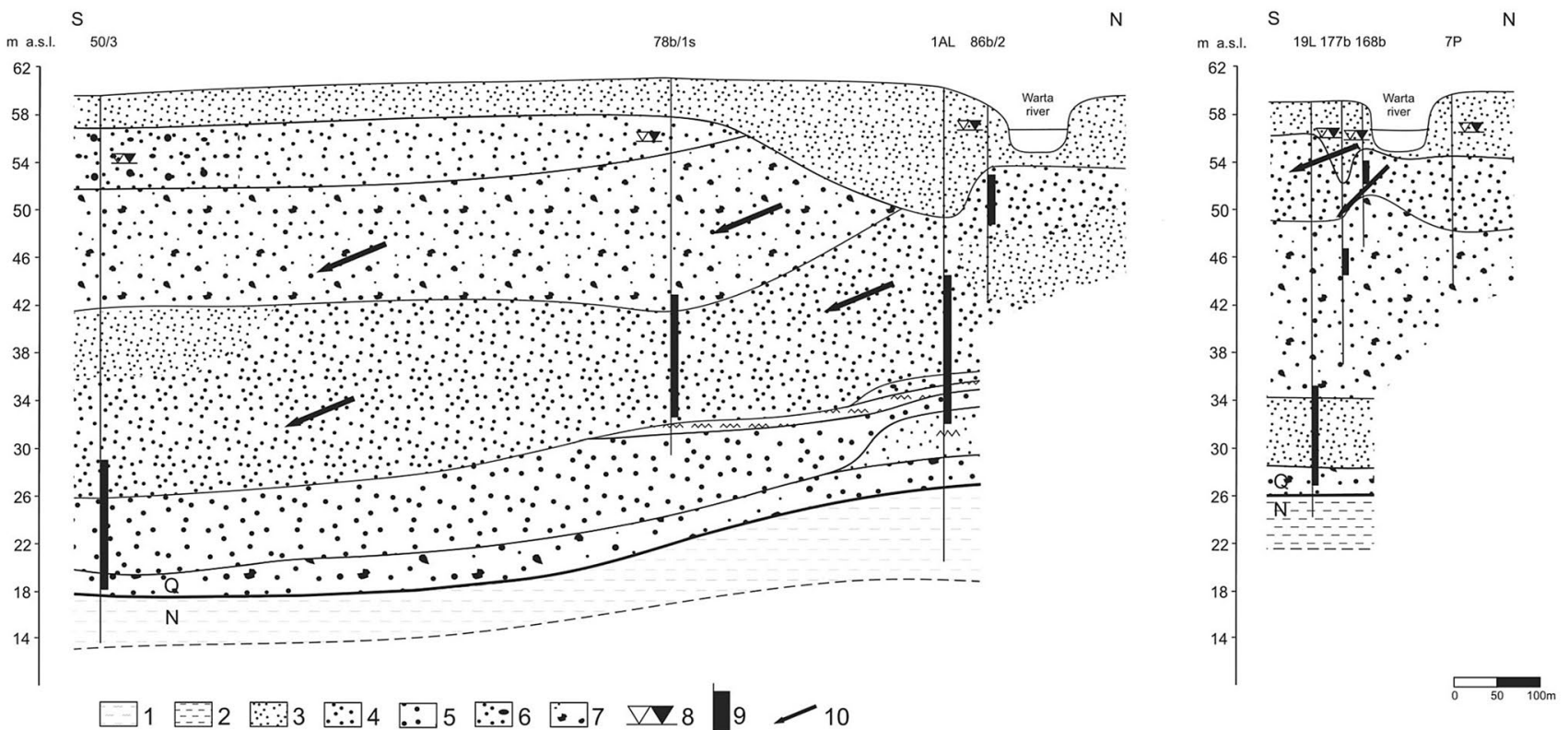

1 - silt, 2 - clay, 3 - fine-grained sand, 4 - medium-grained sand, 5 - coarse-grained sand, 6 - medium-grained sand and gravel, 7 - sand, gravel and pebble, 8 - groundwater level, 9 - well screen, 10 - groundwater flow direction, $Q$ - Quaternary, $N$ - Neogene

Fig. 2 Hydrogeological cross-sections (lines of cross-sections are marked on Fig. 1) 
located $5 \mathrm{~m}$ below the river bottom in the sediments of the shallow aquifer.

In the Krajkowo well field, there is one more well group located between artificial ponds (Fig. 1). This part of the well field was not considered in this study.

The current total well field abstraction is $70,000 \mathrm{~m}^{3} /$ day; the RBF-c yield is $45,000 \mathrm{~m}^{3} /$ day; RBF-f yield is $14,000 \mathrm{~m}^{3} /$ day and the HW yield is $4000 \mathrm{~m}^{3} /$ day.

The wells along two transects were selected to investigate the SOCs behaviour in the RBF system. Transect I was located between the river and the RBF-c production wells and transect II was located between the river and the RBF-f wells. The sampling points along transects were located on the flow paths between the river and pumped wells. These locations permitted the investigation of hydrochemical transformations associated with bank filtration at different distances from the source (river). The position of the well screen at each sampling point is presented in Fig. 2, and detailed characteristics are presented in Table 1.

The total annual precipitation from 1985 to 2017 in the study area is shown in Fig. 3. The average precipitation from this period is $554 \mathrm{~mm}$. Three long dry periods were documented. The first dry period spanned from 1989 to the end of 1992 (until the end of the summer). The second dry period occurred between 2003 and 2006. The other long hydrological drought occurred between 2013 and 2016 and a very wet year occurred in 2017 , as reflected by a notable increase in the water level of the Warta River.

In 2016, the average water level was $56.0 \mathrm{~m}$ a.s.l. and in 2017 , the water level increased more than $57.0 \mathrm{~m}$ a.s.l. (Fig 4).

It was previously documented that after long dry periods, surface water contamination occurs in the study area, as manifested mainly by sharp increases in the nitrate concentration in surface water. This change in nitrate concentration was related to the accumulation of contaminants in the soil and aeration zone during drought periods (lack of effective infiltration to groundwater) and the subsequent transport of these contaminants to groundwater and surface water via recharge infiltration after each drought period (Górski et al. 2019). The nitrate contamination derives from agricultural activities. This scenario reflects pesticides migration patterns similar to those observed in this study.

\section{Materials and methods}

Three sampling campaigns were conducted to investigate SOCs levels in the Krajkowo well field. Two campaigns took place in 2017 (summer and autumn) and one in the winter of 2018. Water was sampled at each sampling point along the selected transects (Table 1, Fig. 2). The Warta River water was also sampled during each campaign. The production wells were continuously pumped before sampling and observation wells were pumped using a portable pump (MP-1 type-Grundfos). Water in the well column was flushed three times before sampling. The water was sampled into $1000 \mathrm{ml}$ HDPE polyethylene bottles and rinsed three times. The bottles were filled completely to prevent degassing. On the same day, water samples were transported to the laboratory. Chemical analyses were performed at the Institute of Plant Protection-National Research Institute in Poznań (Department of Pesticide Residue Research). The studies included more than 200 active substances of plant protection products. All selected pesticides were extracted from water samples by means of solid phase extraction (SPE,

Table 1 Sampling point characterisation (after Górski et al. 2018, modified)

\begin{tabular}{|c|c|c|c|c|c|}
\hline Sampling points & Location & $\begin{array}{l}\text { Distance from } \\
\text { the river bank } \\
\text { (m) }\end{array}$ & $\begin{array}{l}\text { Depth of the well screen } \\
\text { (m) }\end{array}$ & $\begin{array}{l}\text { Contribution of river } \\
\text { water in total water bal- } \\
\text { ance in well (\%) }\end{array}$ & Residence time \\
\hline Warta River & - & - & - & - & - \\
\hline $\begin{array}{l}\text { Collector horizontal } \\
\text { well-HW }\end{array}$ & $\begin{array}{l}\text { Drains under river bot- } \\
\text { tom }\end{array}$ & 0 & $5 \mathrm{~m}$ below river bottom & 100 & A few hours \\
\hline $\begin{array}{l}\text { Observation well no. } \\
168 \mathrm{~b} / 2\end{array}$ & Flood plain & 11 & $5.5-7.5$ & 100 & A few weeks \\
\hline $\begin{array}{l}\text { Observation well no. } \\
177 \mathrm{~b} / 1\end{array}$ & Flood plain & 38 & $12.5-14.5$ & 90 & 1 month \\
\hline $\begin{array}{l}\text { Vertical wells (RBF-c) - } \\
1 \mathrm{AL}\end{array}$ & Flood plain & 82 & $16.5-32.5$ & $65-85$ & $1-3$ months \\
\hline $\begin{array}{l}\text { Vertical wells (RBF-c)— } \\
\text { 19L }\end{array}$ & Flood plain & 64 & $24.0-32.0$ & $65-85$ & $1-3$ months \\
\hline $\begin{array}{l}\text { Observation well no. } \\
78 \mathrm{~b} / \mathrm{s}\end{array}$ & Higher terrace & 250 & $18.0-28.0$ & 60 & 6 months \\
\hline $\begin{array}{l}\text { Vertical well (RBF- } \\
\text { f) }-50 / 3\end{array}$ & Higher terrace & 680 & $31.8-41.8$ & 40 & 1 year \\
\hline
\end{tabular}


800

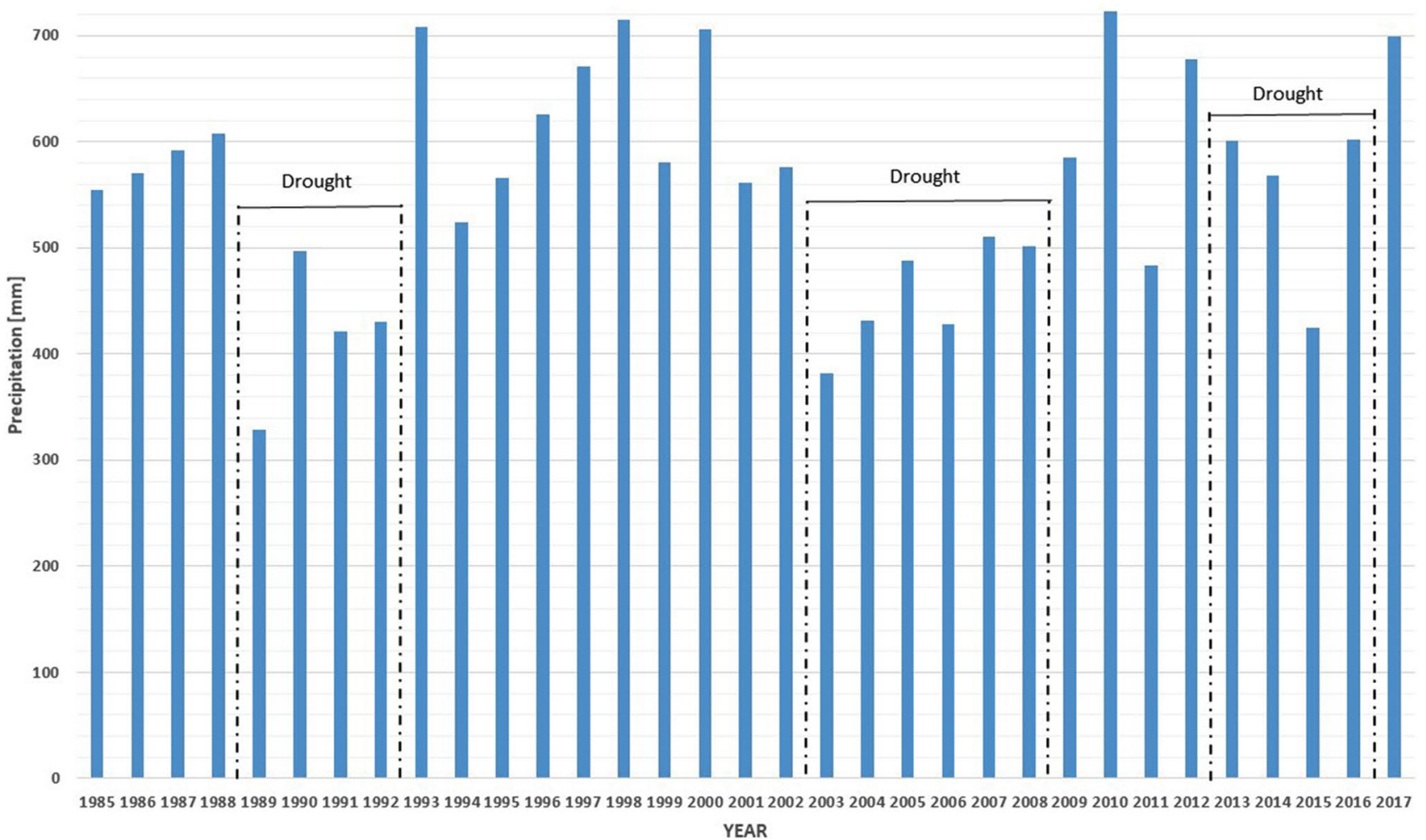

Fig. 3 The average annual precipitation in the Warta River catchment (Poznań-Lawica meteorological gauging station)

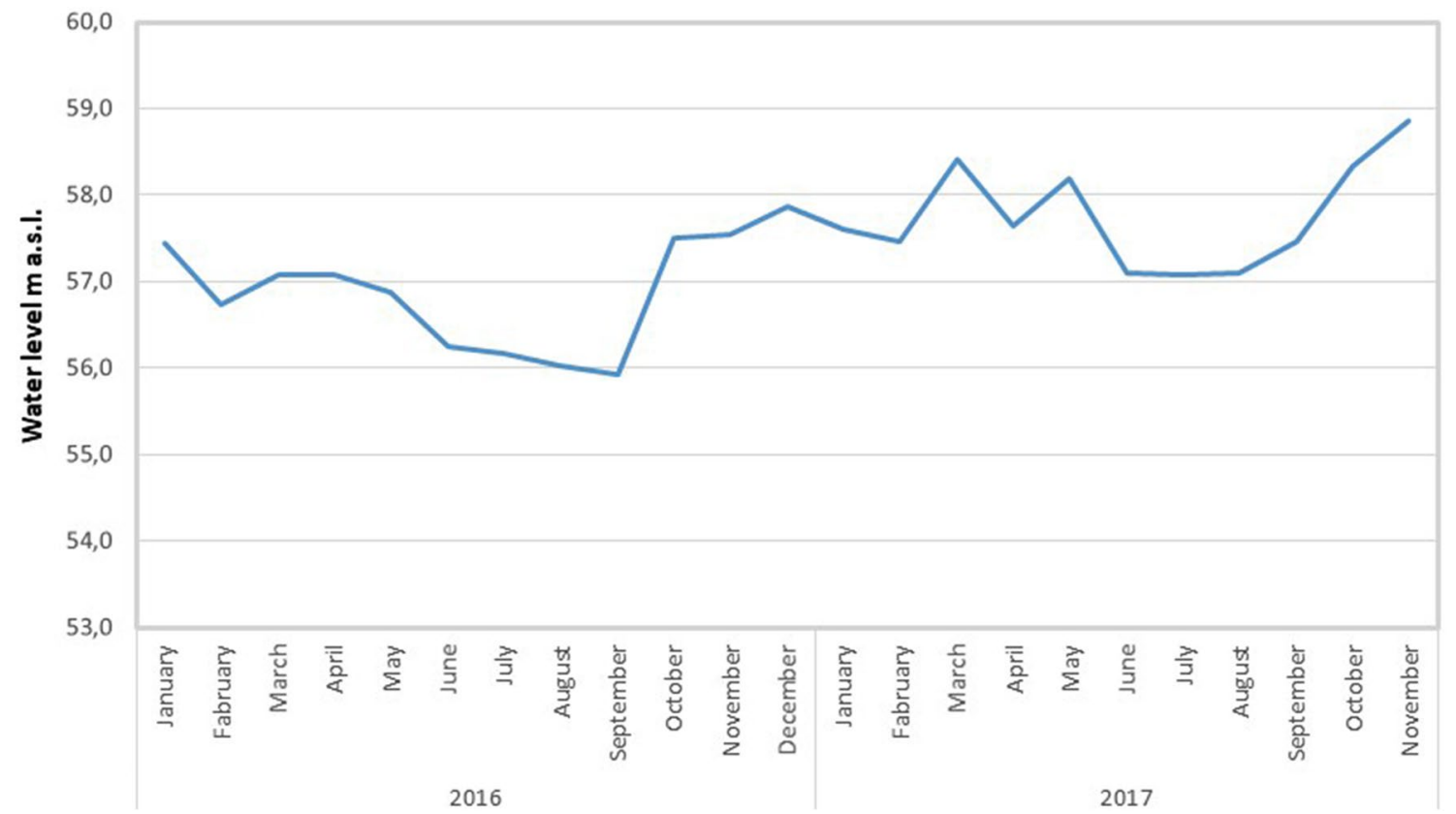

Fig. 4 Fluctuations in the water level of the Warta River 
graphite carbon black). Final determination of investigated compounds was performed using reverse phase ultra-performance liquid chromatography with quadrupole mass spectrometer (RP-UPLC-MS/MS) (Di Corcia et al. 2000; Jeannot et al. 2000). The limits of quantification for all target compounds were calculated at levels of $0.005 \mu \mathrm{g} / \mathrm{l}$, depending on the signal response of the MS detector.

The analysis of temporal changes in SOCs in the Warta River was based on analyses performed at the Rogusko sampling point located $30 \mathrm{~km}$ upstream of Krajkowo. As a reference point, the Mściszewo sampling point located $30 \mathrm{~km}$ downstream was also monitored.

\section{Results}

In the three sampling campaigns 2017-2018, ten active substances associated with PPPs were identified. Among the detected pesticides, eight were authorised for use in plant protection, whereas the herbicide isoproturon has been banned since October 2017. Among the pesticides detected in water samples, 'historical' methylthiotriazine herbicides prometryn and terbutryn (banned since 2007), were persistent in the groundwater samples. Although these herbicides were banned over a decade ago, pesticide residues can remain in agricultural soils. The other identified pesticides are permitted for crop protection and their residues were observed in collected water samples. The compounds represent different types of pesticide activity and they are components of hundreds of PPPs. Detected fungicide such as metalaxyl-M (AI in 14 PPPs) is used in late spring and early summer to protect against potato blight disease. Imidacloprid is an insecticide (AI in 16 PPPs) applied to winter wheat and winter barley in autumn and sugar beets in spring as a seed dressing compound. The other substances were various herbicides. Metazachlor (AI in 50 PPPs) is a soil-applied herbicide used for oilseed rape protection in winter, immediately after sowing or on young plants (summer/autumn). Nicosulfuron (AI in 65 PPPs), terbuthylazine (AI in 18 PPPs) and S-metolachlor (AI in four PPPs) are used for corn crop protection. The first two substances are applied in the early phase of plant growth (spring/summer season), and S-metolachlor is a spring soil-applied herbicide. The final herbicide identified in monitored water samples, chlorotoluron (AI in ten PPPs), was commonly applied to various winter and spring varieties of cereal crops. Chlorotoluron residues can be present in water samples throughout the calendar year.

The temporal changes in the pesticide concentrations in the Warta River (Rogusko sampling point) are presented in Fig. 5. The figure presents the pesticides detected in the Warta River at concentrations above LOQ. In September 2017 , a very sharp peak was observed in the total pesticide concentration. The constituent responsible for this peak was metazachlor, which was documented at a high level in September. Much smaller concentrations were recorded for the remaining constituents, but trends related to the use of particular pesticides were very clear. Clear peaks in S-metolachlor and terbuthylazine after the spring were observed in the river water. In the case of chlorotoluron, an autumn peak is evident. Additionally, the nicosulfuron and tebuconazole concentrations remained high in the river water throughout the year.

The results of the pesticides investigation of the Krajkowo well field are presented in Table 2. In the table, only ten constituents detected at concentrations above the limit of quantification LOQ are presented. During the Warta River sampling campaigns in 2017, seven constituents were detected totalling to $0.112 \mu \mathrm{g} / \mathrm{l}$ in summer and eight constituents totalling to $0.171 \mu \mathrm{g} / \mathrm{l}$ were detected in autumn. In the winter sampling campaign, lower concentrations of pesticides were observed (total detected pesticide concentrations of $0.031 \mu \mathrm{g} / \mathrm{l})$. Similar pesticide concentrations were documented in horizontal well $(0.086,0.137$ and $0.024 \mu \mathrm{g} / \mathrm{l}$, respectively). Much smaller constituent concentrations were detected in the vertical wells. In summer 2017 sampling campaign, three constituents were detected, with total concentrations of 0.045 and $0.058 \mu \mathrm{g} / \mathrm{l}$ in wells $1 \mathrm{AL}$ and $19 \mathrm{~L}$, respectively. In the autumn campaign, the total pesticide levels were 0.046 and $0.058 \mu \mathrm{g} / \mathrm{l}$ in wells $1 \mathrm{AL}$ and $19 \mathrm{~L}$, respectively. Seven constituents were detected in well $1 \mathrm{AL}$ and five were observed in well 19L. In the winter sampling campaign, only chlorotoluron was detected $(0.014 \mu \mathrm{g} / \mathrm{l}$ in both wells). The concentrations of pesticides in piezometer located between the river and RBF-c wells were intermediate that reflected the successive concentration reduction during bank filtration. Pesticides were not detected in the RBF-f well, and only isoproturon was detected in well 78b/l at concentrations of $0.019,0.023$ and $0.024 \mu \mathrm{g} / \mathrm{l}$ during the three sampling campaigns. Moreover, chlorotoluron was observed in this well in winter 2018.

For the 2017 sampling series, constituents not observed in the Warta River and HW were observed in vertical wells and some constituents (e.g., chlorotoluron and isoproturon) detected in the river in 2017 appeared in the RBF-c wells in winter 2018. Pesticide concentrations similar to those observed in the Warta River and HW were also detected in observation well $168 \mathrm{~b} / 1$, which was located very close to the river channel (Table 1), but these similarities were only observed for the 2017 summer sampling campaign. 
Environmental Earth Sciences (2019) 78:593

Page 7 of 11

593
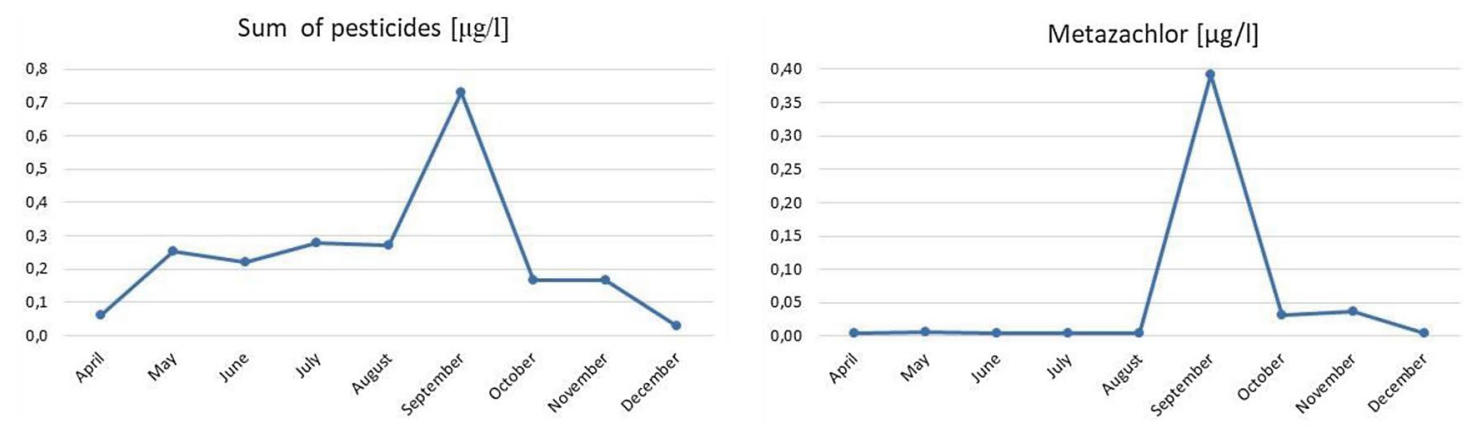

Chlorotoluron $[\mu \mathrm{g} / \mathrm{l}]$

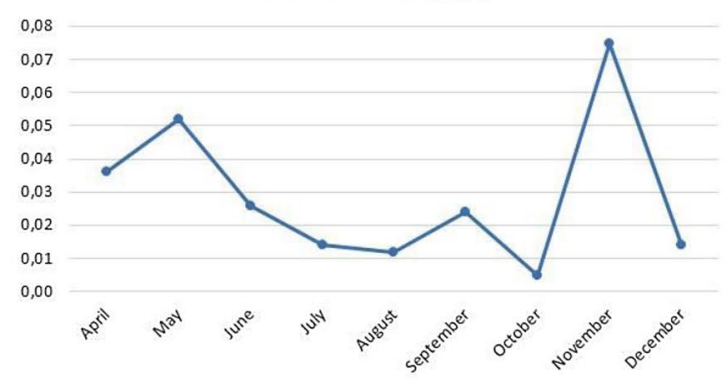

Nicosulfuron $[\mu \mathrm{g} / \mathrm{l}]$

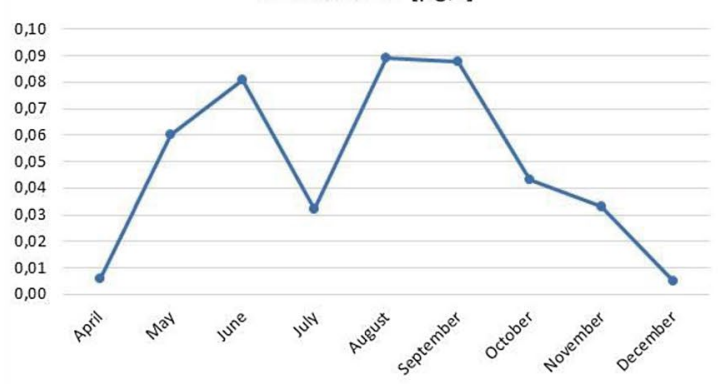

Terbutryne $[\mu \mathrm{g} / \mathrm{l}]$

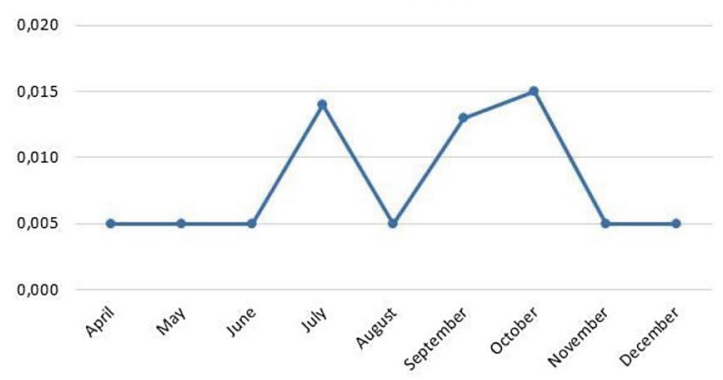

Propiconazole $[\mu \mathrm{g} / \mathrm{l}]$

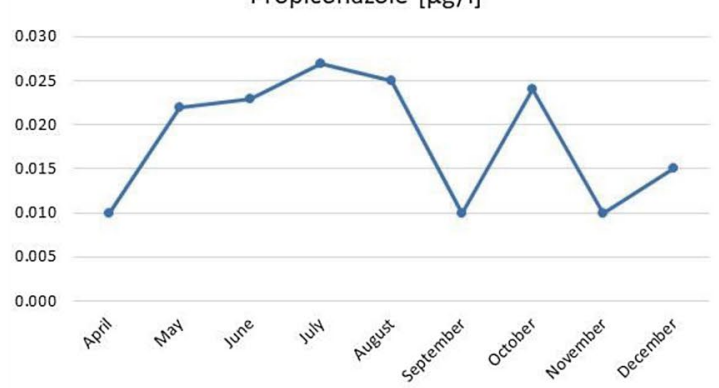

S-Metolachlor $[\mu \mathrm{g} / \mathrm{l}]$

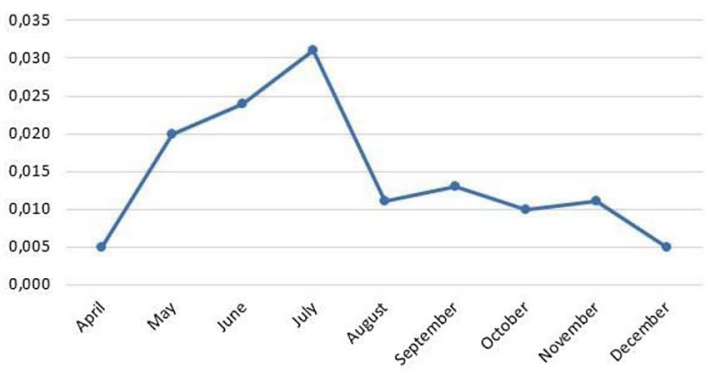

Tebuconazole $[\mu \mathrm{g} / \mathrm{l}]$

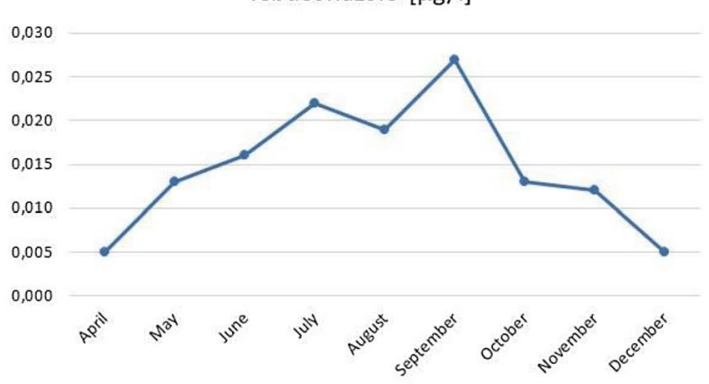

Terbuthylazine $[\mu \mathrm{g} / \mathrm{l}]$

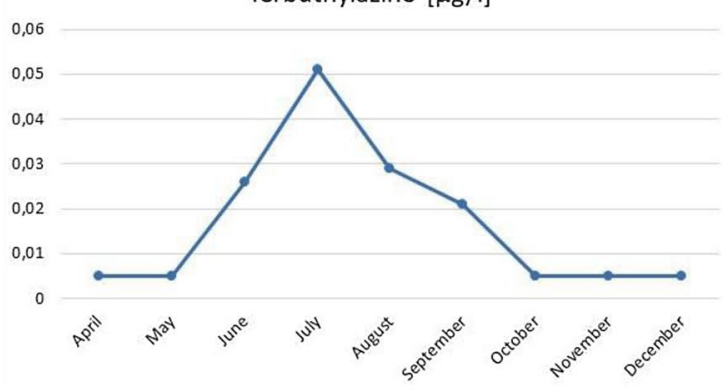

Isoproturon $[\mu \mathrm{g} / \mathrm{l}]$

0.020

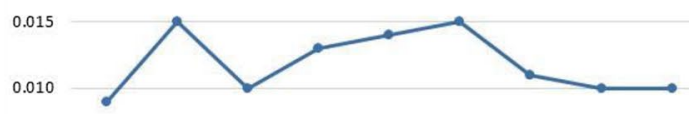

0.005

0.000

$p^{s i}$

Fig. 5 The temporal changes in pesticide concentrations in 2019 year in the Warta River (Rogusko sampling point)

Springer 


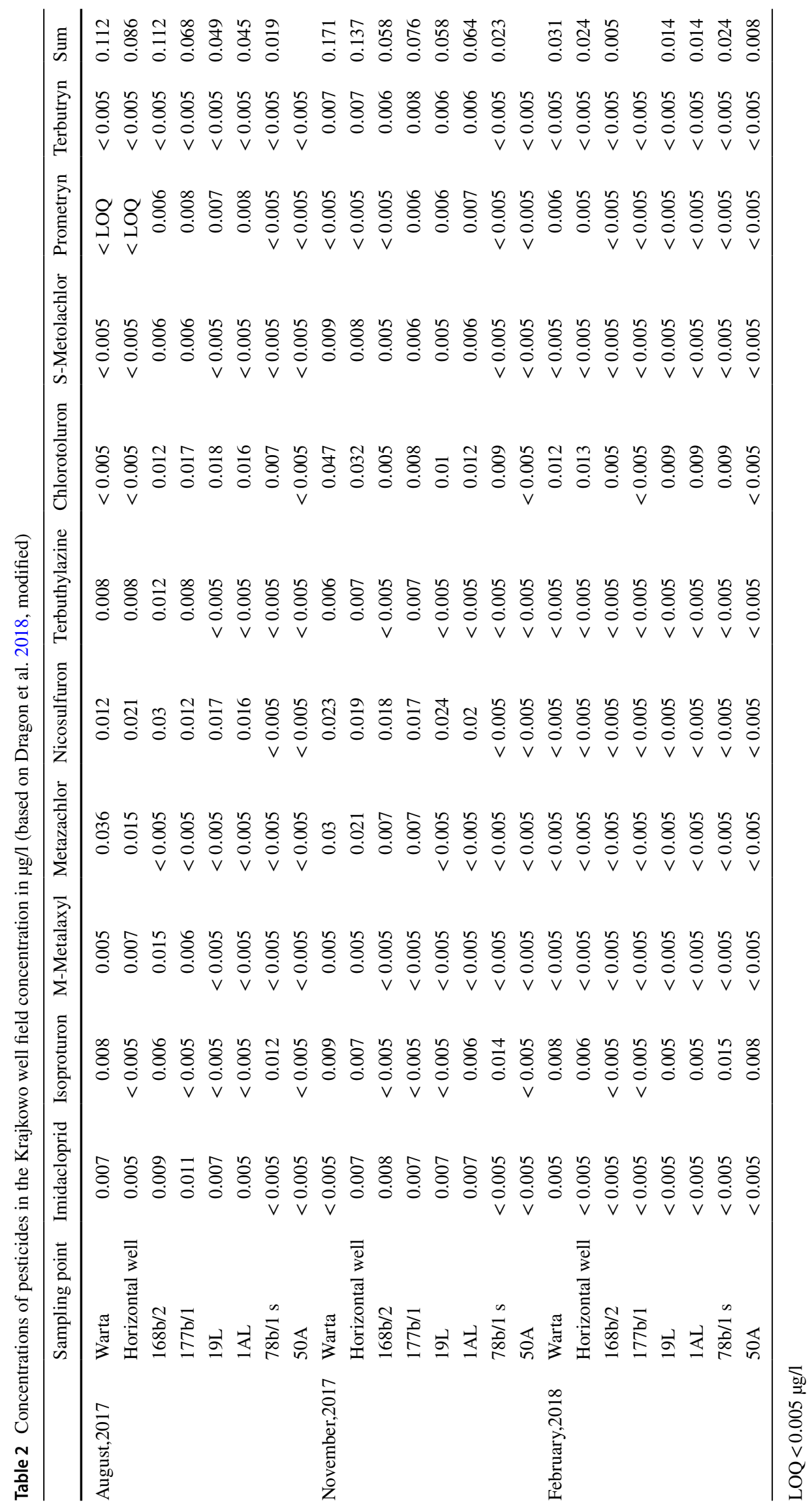




\section{Discussion}

The temporal changes in pesticide concentrations indicate that the highest concentrations were observed during the autumn sampling campaigns. In summer, the concentrations were also relatively high, and in winter, the observed concentrations were significantly lower. The observed trends are related to two factors. The first factor is related to the pesticides used by farmers. The most intensive application of SOCs by farmers generally occurs in spring and late summer/early autumn. The second factor is related to hydrological conditions. If there is no rain, the pesticides accumulate in the soil and migration is limited. However, during wet periods, the pesticide residues that accumulate in the soil are removed from the soil matrix by infiltration and then transported through the aeration zone and into groundwater along flow paths. This factor (especially the long wet season) can facilitate the migration of most durable constituents that accumulate in the environment. Among the factors that facilitate pesticide migration, drainage systems transport agricultural contaminants from the soil and shallow groundwater directly to surface water (Dragon et al. 2016). The peak pesticide concentrations observed in the Warta River was related to relatively intensive precipitation in Poland in 2017 (Fig. 3), as reflected by the high water level in the Warta River (highest since September 2016; Fig. 4). These conditions enabled the removal of contaminants from the soil zone via effective infiltration and contaminant transport to the river.

The smallest pesticide concentrations in winter 2018 reflect a large-scale removal of pesticide residues from the soil zone. Consequently, only the most persistent substances were detected in the Warta River in winter 2018 (prometryn, isoproturon and chlorotoluron). These pesticides can persist in the soil for at least 3 years after application and can then be mobilised by increasing rainwater (Johnson et al. 2001). These persistent components that were applied and accumulate during the long dry seasons between 2013 and 2016, then washed from the soil during the wet season in 2017. This mechanism also caused pesticides that have been banned for long periods and are not applied by farmers to appear in water samples. For example, terbutryn and prometryn were detected in both the river and wells in 2017, but have been banned in Poland since 2007.

From a spatial perspective, pesticide concentrations clearly decrease due to bank filtration (Fig. 6). The similar constituents and concentrations detected in the river and HW indicate that the well is vulnerable to pollution from the river. The drains located $5 \mathrm{~m}$ below the river bottom do not increase the travel time enough to remove contaminants from the drained water. More effective contaminants removal was achieved in vertical wells located 60-80 from the river (RBF-c wells). The total pesticide concentrations in the well were much lower than those in the river, but some contaminants were still present in extracted water (Fig. 6). Additionally, in all the sampling campaigns, constituents that were not observed in the river samples were observed in the wells, likely due to the 1-3 month travel time of bank filtrate between the river and wells. Thus, the wells contained constituents that were present in the river before sampling. In the 2017 sampling campaigns, prometryn, nicosulfuron and chlorotoluron were detected in the RBF-c wells (but not in the river water).

The RBF-f well locations were associated with a 1-year bank filtrate travel time (Table 1). The results show that this
Fig. 6 The sum of pesticide concentrations along flow path

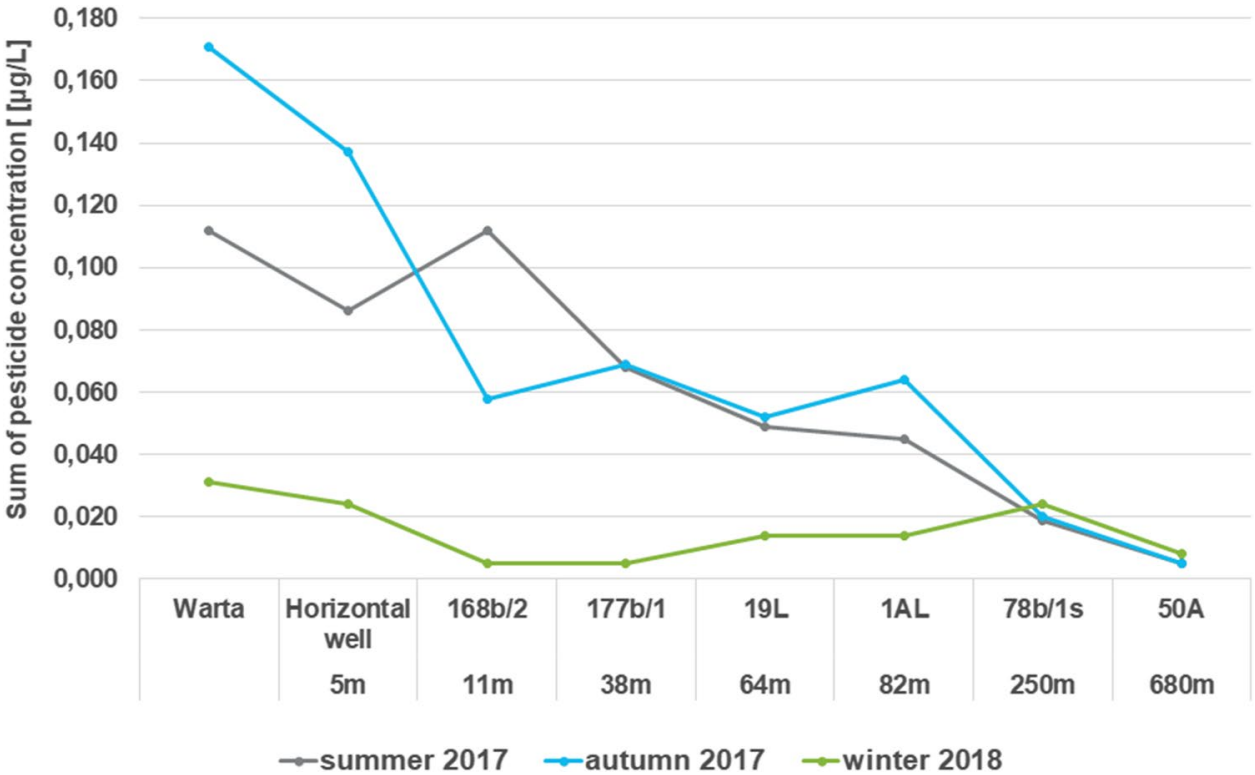


amount of time is sufficient for the removal of contaminants that occur in bank filtrate. Notably, only isoproturon and chlorotoluron were observed in a well located $250 \mathrm{~m}$ from the river (in all sampling series), and only isoproturon was detected at a concentration slightly above LOQ in well 50A located $680 \mathrm{~m}$ from the river (Table 2).

The results of present work confirm earlier findings of higher efficiency of contaminant removal by the river bank filtration system composed by vertical wells located 60-80 $\mathrm{m}$ from the river than HW that receive river water after a very short travel time (horizontal drains located $5 \mathrm{~m}$ below river bottom). It also confirms that for effective micropollutants removal, vertical wells should be placed more than $100 \mathrm{~m}$ from the river. Suggested distance of wells from the river channel is 150-200 m, ensuring half year of bank filtrate travel time (Górski et al. 2018).

The observed behaviour of pesticides is very similar to other micropollutants (i.e. pharmaceuticals), confirming good effectiveness of RBF systems in removal of organic micropollutants (Dragon et al. 2018). One factor that influences contaminant concentrations in extraction wells is the mixing of bank filtrate and ambient groundwater. In RBF-c wells, $65-85 \%$ of water is derived from bank filtration, and in RBF-f wells, this percentage is $\sim 40 \%$ (Table 1 ). This mixing leads to the dilution of contaminants in bank filtrate.

It should be noted that detected pesticides are at lower concentrations than permissible limits (EC 1998, 2006; Rozporzadzenie 2017) in both: surface (source) water and in bank filtrate. It is related to total pesticides concentrations as well as to individual substances.

\section{Conclusions}

The results of three sampling campaigns conducted at a RBF site located in Krajkowo (Poland) in summer and autumn 2017 and in winter 2018 indicated the presence of pesticide residues in source water (Warta River) as well as in bank filtrate.

The temporal changes in pesticide concentrations in the Warta River exhibited clear differentiation related to periods of intensive SOCs use (spring and summer/autumn), as manifested by clear peak constituent levels in the river after these periods. Clear S-metolachlor and terbuthylazine peaks were observed after applications during spring and chlorotoluron exhibited an autumn peak. Additionally, nicosulfuron and tebuconazole were detected in the river water throughout the year.

SOCs concentrations similar to those detected in the river water were observed in the horizontal well (HW), with the drains located $5 \mathrm{~m}$ below the river bottom. This finding reflects the high vulnerability of HW to pesticide contamination from the river.
In the vertical wells and observation wells located along the flow path between the river and sampling points, gradual reduction of pesticide concentrations was observed. The removal rate depends on distance from the river and travel time as well as share of river water and groundwater in wells recharge.

In vertical wells located relatively close to the river (60-80 m), the total pesticide concentrations were much lower than in the river, but some pesticides were still present in water. The most effective SOC removal was observed in wells located $680 \mathrm{~m}$ from the river (RBF-f), where only one component (isoproturon) was detected in winter 2018 sampling series at a concentration slightly above LOQ. The well located $250 \mathrm{~m}$ from the river also exhibited a high contaminant removal rate (only isoproturon and chlorotoluron were detected).

The results confirm the effectiveness of RBF in the removal of contaminants observed in source water (in this case, river water). The research confirms earlier findings that, from the water quality perspective, suggest RBF wells location should be 150-200 $\mathrm{m}$ from the river (half year of residence time) to achieve effective contaminant removal.

Acknowledgements This research was completed with the support from the AquaNES project. This project has received funding from the European Union's Horizon 2020 Research and Innovation Program under grant agreement no. 689450. The authors would like to thank Aquanet SA (Poznan Waterworks operator) for their contribution and help in data collection.

Open Access This article is distributed under the terms of the Creative Commons Attribution 4.0 International License (http://creativeco mmons.org/licenses/by/4.0/), which permits unrestricted use, distribution, and reproduction in any medium, provided you give appropriate credit to the original author(s) and the source, provide a link to the Creative Commons license, and indicate if changes were made.

\section{References}

Badach H, Nazimek T, Kamińska IA (2007) Pesticide content in drinking water samples collected from orchard areas in central Poland. Ann Agric Environ Med 14(1):109-114

Barchańska H, Sajdak M, Szczypka K, Swientek A, Tworek M, Kurek M (2017) Atrazine, triketone herbicides, and their degradation products in sediment, soil and surface water samples in Poland. Environ Sci Pollut Res Int 24(1):644-658

Di Corcia A, Nazzari M, Rao R, Samperi R, Sebastiani E (2000) Simultaneous determination of acidic and non-acidic pesticides in natural waters by liquid chromatography-mass spectrometry. J Chromatogr A 878(1):87-98

Dragon K, Kasztelan D, Gorski J, Najman J (2016) Influence of subsurface drainage systems on nitrate pollution of water supply aquifer (Tursko well-field, Poland). Environ Earth Sci 75:100

Dragon K, Gorski J, Kruc R, Drozdzynski D, Grischek T (2018) Removal of natural organic matter and organic micropollutants during riverbank filtration in Krajkowo, Poland. Water 10:1457 
Drozdzynski D (2008) Studies on residues of pesticides used in rape plants protection in surface waters of intensively exploited arable lands in Wielkopolska Province of Poland. Ann Agric Environ Med 15(2):231-235

European Commission (EC) (1998) Council Directive 98/83/EC of 3 November 1998 on the quality of water intended for human consumption. Off. J. Europ. Union L327/1. 22/12/2000

European Commission (EC) (2006) Directive 2006/118/EC of the European Parliament and the Council of 12th December 2006 on the protection of ground water against pollution and degradation. Off. J. Europ. Union L372/19. 27/12/2006

Forizs T, Berecz Z, Molnar Z, Suveges M (2005) Origin of shallow groundwater of Csepel Island (south of Budapest. Hungary. River Danube): isotopic and chemical approach. Hydrol Process 19:3299-3312

Ghodeif K, Grischek T, Bartak R, Wahaab R, Herlitzius J (2016) Potential of river bank filtration (RBF) in Egypt. Environ Earth Sci 75:671

Gorski J, Dragon K, Kruc R (2018) A comparison of the efficiency of riverbank filtration treatments in different types of wells. Geologos 24(3):245-251

Gorski J, Dragon K, Kaczmarek P (2019) Nitrate pollution in the Warta River (Poland) between 1958 and 2016: trend and causes. Environ Sci Pollut Res 26:2038-2046

Guzzella L, Pozzoni F, Giuliano G (2006) Herbicide contamination of surficial groundwater in Northern Italy. Environ Pollut 142:344-353

Hiscock KM, Grischek T (2002) Attenuation of groundwater pollution by bank filtration. J Hydrol 266:139-144

Jeannot R, Sabik H, Sauvard E, Genin E (2000) Application of liquid chromatography with mass spectrometry combined with photodiode array detection and tandem mass spectrometry for monitoring pesticides in surface waters. J Chromatogr A 879(1):51-71

Johnson AC, Besien TJ, Bhardwaj CL, Dixon A, Gooddy DC, Haria AH, White C (2001) Penetration of herbicides to groundwater in an unconfined chalk aquifer following normal soil applications. J Contam Hydrol 53:101-117

Köck-Schulmeyer M, Ginebreda A, Postigo C, Garrido T, Fraile J, López de Alda M et al (2014) Four-year advanced monitoring program of polar pesticides in groundwater of Catalonia (NESpain). Sci Total Environ 2014(470-471):1087-1098

Kovačević S, Radišić M, Laušević M, Dimkić M (2017) Occurrence and behavior of selected pharmaceuticals during riverbank filtration in The Republic of Serbia. Environ Sci Pollut Res 24:2075-2088

Lasagna M, De Luca DA, Franchino E (2016) Nitrates contamination of groundwater in the western Po Plain (Italy): the effects of groundwater and surface water interactions. Environ Earth Sci $75: 240$

Loos R, Locoro G, Comero S, Contini S, Schwesig D, Werres F et al (2010) Pan-European survey on the occurrence of selected polar organic persistent pollutants in ground water. Water Res 44:4115-4126

Postigo C, Barcelo D (2015) Synthetic organic compounds and their transformation products in groundwater: occurrence, fate and migration. Sci Total Environ 503-504:32-47

Przybyłek J, Dragon K (2017) Kaczmarek P (2017) Hydrogeological investigations of river bed clogging at a river bank filtration site along the River Warta, Poland. Geologos 23:201-214

Ray C, Soong TW, Lian YQ, Roadcap GS (2002) Effect of floodinduced chemical load on filtrate quality at bank filtration sites. $\mathrm{J}$ Hydrol 266:235-258

Reh R, Licha T, Geyer T, Nödler K, Sauter M (2013) Occurrence and spatial distribution of organic micro-pollutants in a complex hydrogeological karst system during low flow and high flow periods, results of a 2-year study. Sci Total Environ 443:438-445

Rozporządzenie Ministra Zdrowia z dnia 07 grudnia 2017 r. w sprawie jakości wody przeznaczonej do spożycia przez ludzi (Dz.U. 2017 nr 2294)

Sandhu C, Grischek T, Kumar P, Ray C (2011) Potential of Riverbank filtration I India. Clean Technol Environ Policy 13:295-316

Sprenger C, Lorenzen G, Hulshoff I, Grutzmacher G, Ronghang M, Pekdeger A (2011) Vulnerability of bank filtration systems to climate change. Sci Total Environ 409:655-663

Publisher's Note Springer Nature remains neutral with regard to jurisdictional claims in published maps and institutional affiliations. 